\title{
Status and Scope of Women Entrepreneurship
}

\author{
Deepa Vinay, Divya Singh* \\ Department of Family Resource Management, G.B.Pant Agriculture University of Technology, India
}

Copyright $@ 2015$ Horizon Research Publishing All rights reserved.

\begin{abstract}
Woman constitutes the family, which leads to society and Nation. Social and economic development of women is necessary for overall economic development of any society or a country and Entrepreneurship is the state of mind which every woman has in her but has not been capitalized in India in the way in which it should be. So women entrepreneur is a person who accepts challenging role to meet her personal needs and become economically independent. A strong desire to do something positive is an inbuilt quality of entrepreneurial women, who is capable of contributing values in both family and social life. They are involved in business activities at all levels, making important contributions to economic growth. While many women are succeeding in business, they are still constrained by the gender values, norms and stereotypes in the environment in which they operate. Because of their reproductive roles they tend to be responsible for business as well as for most of the unpaid work in the household. They have less time to devote to their work and they are less mobile. A key issue, therefore, is whether women entrepreneurs face specific problems in setting up in business that is different from those faced by male-owned businesses. The present article deals with the concept of women entrepreneur, reasons to become entrepreneurs, advantages of women entrepreneur, present status, impediments, measures to remove obstacles, steps taken by the Indian Government in term of five year plans, schemes for promotion \& development of women entrepreneurship in India and some leading women entrepreneurs of India.
\end{abstract}

Keywords Entrepreneur, Gender Inequality, Women, Gender, Business

\section{Introduction}

Time immemorial, women are described as the better half of men. But in reality, the women in developing countries do not tally with this description. It is well known fact that women have played and continue to play a key role in conservation of basic life support systems such as land, water, flora and fauna. Women have to play a dual role, as a housewife and as income earners. Women have the burden of preparing food for the family, besides fulfilling their fundamental role of nurturing and caring for the children and tending to elderly members of the household. Even then they suffer from being economically and socially invisible. There is continued inequality and vulnerability of women in all fields like socio-economic, political, education, health care, nutrition etc. [22]

Now a day educated women do not want to limit their lives in the four walls of the house. They demand equal respect from their partners. However, Indian women have to go a long way to achieve equal rights and position because traditions are deep rooted in Indian society where the sociological set up has been a male dominated one. Women are considered as weaker sex and always made to depend on men folk in their family and outside, throughout their life. The Indian culture made them only subordinates and executors of the decisions made by other male members, in the basic family structure. While at least half the brainpower on earth belongs to women, women remain perhaps the world's most underutilized resource. Despite all the social hurdles, India is brimming with the success stories of women. They stand tall from the rest of the crowd and are applauded for their achievements in their respective field. The transformation of social fabric of the Indian society, in terms of increased educational status of women and varied aspirations for better living, necessitated a change in the life style of Indian women. She has competed with man and successfully stood up with him in every walk of life and business is no exception for this. These women leaders are assertive, persuasive and willing to take risks. They managed to survive and succeed in this cut throat competition with their hard work, diligence and perseverance. Ability to learn quickly from her abilities, her persuasiveness, open style of problem solving, willingness to take risks and chances, ability to motivate people, knowing how to win and lose gracefully are the strengths of the Indian women Entrepreneurs [10].

Women constitute nearly one half of the world's population having enormous potential but being underutilized or unutilized for the economic development of the nation. Indian situation is not an exception for this. The 2001 census of India estimated 0.53 million females against 
a total population of 1.02 million. In India, women have remained as a neglected section of work force. They were not considered on par with men. Women are lagging behind men mainly because of the relative absence of economic opportunities and minimal participation in decision making process. Women's access to land ownership is extremely limited. Educational backwardness is another major reason why women are lagging behind men. The latest census reports 2001 revealed that female literacy rate in India was 54 per cent, as compared to the male literacy rate of 76 per cent. However, the life expectancy of female was 65 years in contrast to 64 years of male.

Al through small businesses owned by women have traditionally focused on fashion, fond and other services sector, but recently women entrepreneurs have been moving rapidly into manufacturing, construction and other industrial filed. Women owned business are lightly increasing in the economics of almost all countries. The hidden entrepreneurial potential of women has gradually been changing with the growing sensitivity to the role and economic status in the society. It means women have the potentials, skill, knowledge and adaptability to run a business successfully.

The Government of India has defined a women entrepreneur is "an enterprise owned and controlled by a women having a minimum financial interest of $51 \%$ of the capital and giving at least $51 \%$ of the employment generated in the enterprise to women". Women entrepreneur is a person who accepts challenging role to meet her personal need and become economically independent. There are economical, social, religious, cultural and other factors existing in the society which responsible for the emergency of the entrepreneurs. "Women entrepreneur refers equally to someone who has started a one women business to someone who is a principal in family business or partnership or to someone who is shareholder in a public company which she runs".

\section{Review of Literature}

Women in India reveal that empowerment of women and development of women entrepreneurs to bring actual reality through constitutional goal of equality. [13] on "Women Entrepreneurs" Challenges and Strategies" analyses major constraints faced by women entrepreneurs and reflects upon specific policies and programmes for women entrepreneurship development. [19] on Women Entrepreneurs has made an attempt to diagnose the women entrepreneurs profile and has identified dominating entrepreneurial traits, their motivational forces and performance both quantitatively as well as qualitatively. This work aimed at understanding the entrepreneurial development among women is a unique attempt for highlighting their existing status and contribution in the national economy. [11] performed a study on finding the relationship between elements of human capital and self-employment among women. The study showed that self-employed women differ on most human capital variable as compared to the salary and wage earning women. [20] identifies the reasons \& influencing factors behind entry of women in entrepreneurship and mentioned the obstacles in the growth of women entrepreneurship are mainly lack of interaction with successful entrepreneurs, social un-acceptance, family responsibility, gender discrimination, missing network, low priority given by bankers to provide loan. He suggested the remedial measures like promoting micro enterprises, unlocking institutional frame work, projecting \& pulling to grow \& support the winners etc. [1] compared \& evaluated various research studies done on entrepreneurship including women entrepreneurship. It summaries various studies in this way that female entrepreneurs are relatively well educated in general but perhaps not in management skills, high in internal locus of control, more masculine, or instrumental than other women in their values likely to have had entrepreneurial fathers, relatively likely to have frts born or only children, unlikely to start business in traditionally male dominated industries \& experiencing a need of additional managerial training. [12] performed a study to explore the role of women entrepreneurs in a global economy. The study has shown that the women business owners are making significant contributions to global economic health, national competitiveness and community commerce by bringing many assets to the global market. As per the analysis of the research study, women entrepreneurs have demonstrated the ability to build and maintain long-term relationships and networks to communicate effectively, to organize efficiently, to be fiscally conservative, and to be aware of the needs of their environment and to promote sensitivity to cultural differences. Researchers contend that women business owners.

\section{Present Position of Women Entrepreneurs}

Out of the total 940-48 million people in India in the 1990 's of the female comprise of $465 \%$ of the total population. There are 126.48 million women work force (representing $28.9 \%$ of the female population) but as per the 1991 census only 185900 women accounting for only $4.5 \%$ of total self-employed persons in the country were recorded. Majority of them are engaged in the unorganized sectors like agriculture, agro based industries, handicrafts, handloom and cottage based industries. As per the 2001 census report, there are of women workers of the total working population including formal as well as informal sector. In the era of L.P.G (Liberalization, Privatization, Globalization) the Indian women entrepreneurs are very fast entering the non traditional sectors. Which indeed is in response to their greater awareness?

\section{Reasons for Women Becoming Entrepreneurs}

The glass ceilings are shattered and women are found indulged in every line of business. The entry of women into 
business in India is traced out as an extension of their kitchen activities, mainly 3P's, Pickle, Powder and Pappad. But with the spread of education and passage of time women started shifting from 3P's to modern 3E's i.e., Energy, Electronics and Engineering. Skill, knowledge and adaptability in business are the main reasons for women to emerge into business ventures. [10]

Self-determination, expectation for recognition, self-esteem and career goal are the key drivers for taking up entrepreneurship by women. [16] Sometimes, women chose such career path for discovering their inner potential, caliber in order to achieve self-satisfaction (Figure 1). It can also provide a mean to make best use of their leisure hours. However, dismal economic conditions of the women arising out of unemployment in the family and divorce can compel women into entrepreneurial activities.

\section{Impediments to Women Entrepreneurship}

1) Access to finance: Finance is a critical resource for venture creation. It is very important that women entrepreneurs have adequate knowledge and information of the various financial institutions which are rendering financial incentives and many other help for the women entrepreneurs in the region. Women entrepreneurs in
Manipur lacks financial skills as they did not understand hidden costs and anticipate appropriate cash requirement. They have to depend on own saving as the lending practices of banks and government funding agencies are believed to be restrictive and unfriendly to women. Normally banks are blamed for not financing women. Banks don"t have doubt on women capability as they do not consider gender while financing but they place high premium on security of principal and interest amount that is why they take mortgage on bank finance

2) Access to markets: The ability to tap into new markets requires expertise, knowledge and contacts. Women often lack access to training and experience in on how to participate in the market place and are therefore unable to market goods and services strategically. In addition, they have often not been exposed to the international market, and therefore lack knowledge about what is internationally acceptable. The high cost of developing new business contacts and relationships in a new country or market is a big deterrent and obstacle in particular women-owned businesses. Women may also fear or face prejudice or sexual harassment, and may be restricted in their ability to travel to make contacts

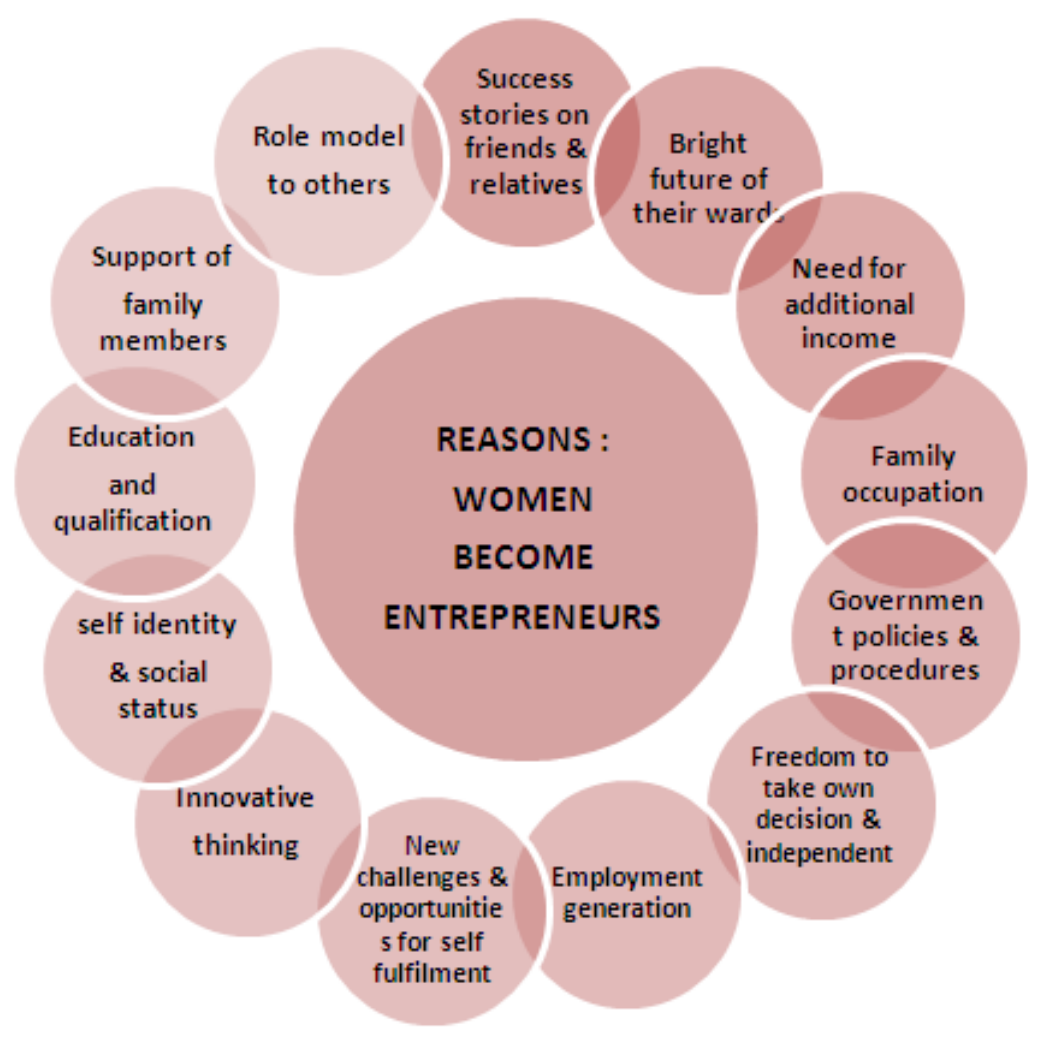

Source : www.zenithresearch.org.in

Figure 1. Reasons of women becomes entrepreneur 
3) Access to training: Women have limited access to vocational and technical training. In fact, women on average have less access to education than men, and technical and vocational skills can only be developed on a strong foundation of basic primary and secondary education. India accounts for $30 \%$ of the world's total illiterate population and around $70 \%$ of these illiterates are women. As per 2001 Census data, women constitute $48 \%$ of the total population in India, but around $46 \%$ of women are still found to be illiterate. Problems of gender disparity and discrimination begin with access to schooling. The Gender Parity Index (GPI) at the primary and upper primary levels was 0.9 and 0.8 in 2003 respectively. The table below shows female literacy levels as a percentage of male literacy as well as average years of schooling of women and men, respectively. The figures are testifying to the existence of gender discrimination in building capacity of women and providing them with equal opportunities. Gaining relevant skills and knowledge can also be more difficult for women since they frequently have double work burden and childcare responsibilities, thus making them less able than men to attend formal and informal trainings [14]

4) Access to networks: Since most women entrepreneurs operate on a small scale, and are generally not members of professional organizations or part of other networks, they often find it difficult to access information. Most existing networks are male dominated and sometimes not particularly welcoming to women but prefer to be exclusive. Even when a woman does venture into these networks, her task is often difficult because most network activities take place after regular working hours. There are hardly any women-only or women-majority networks where a woman could enter, gain confidence and move further. Lack of networks also deprives women of awareness and exposure to good role models. Few women are invited to join trade missions or delegations, due to the combined invisibility of women-dominated sectors or subsectors and of women as individuals within any given sector.

5) Access to policymakers: Most women have little access to policymakers or representation on policymaking bodies. Large companies and men can more easily influence policy and have access to policymakers, who are seen more as their peers. Women tend not to belong to, and even less reach leadership positions in, mainstream business organizations, limiting their input into policymaking through lobbying. Women's lack of access to information also limits their knowledgeable input into policymaking.

\section{Other Impediments to Women Entrepreneurship}

1) Operational: Women entrepreneur in India not only struggle at the time of establishment of enterprises but at operation stage also, they have lots to overcome with different functional difficulties. Usually women faced two fold operational problems. One she has to overcome with problems of production process like, scarcity of raw material, lack of technical skills, lack of utilities and infrastructure facility.

2) Management Problem: It is normally believed that women have low managerial skill. But in fact women are stronger in more logic based skills though they are weaker in self-promotion and handling frustration. The increasing number of female students and their excellent performance in management education is a proof to the fact. They don't lack managerial skills but they have less promotional stability which they need to improve upon it.

3) Mobility Constraints: Women in India have got restricted mobility, our society is a conservative society, and the career of women was limited to four walls of kitchen. Though women faced lots of problems being mobile in entrepreneurial activity, the mobility problem has been solved to certain extent by the expansion of education awareness to all.

4) Dual Responsibility: The most exploited individual of the day are the working women, as they have to perform dual responsibility, one at work and another as family as mother of wife. The level of women exploitation on family responsibility ground depends on her social dependence.

5) Risk-Bearing Ability: One pre-requisites of the entrepreneurial success is risk taking. It is normally believe that women being feminist gender have low risk taking ability. A Manipuri woman lives a protected life. The society feels that women do not have risk taking ability. They are being suppressed by the protected environment and are not allowed most of the time to take any type of risk even if she is willing or she has the ability to bear.

6) Unawareness of the Supports and Incentives: India being a developing country has made efforts at both central as well as state level to solve this problem by way of introducing policy measures and promoting NGO"s. The government of India in its annuals often announces special growth and provision to assist self-employment in women. But it has not worked out effectively and very few women entrepreneurs are able to avail them. Despite the efforts the problem still exists as most of the women entrepreneurs in the region have neither approach nor awareness about these policies due to low education level. Women engage in this venue are unhappy with support system due to harassment from the officials and high corruption. There is a strong need for attitudinal change because policies, programmes and seminars alone cannot change the women status.

7) Traditional views on the role of women in the society: The often prevailing attitude that the women's place is at home and that her first priority is to look after the home and family constrain many married women from venturing into entrepreneurship. Even for the women who are interested, the fact that marriage often results in geographical displacement, makes serious entrepreneurship the last option.

8) Statistical invisibility: Most countries do not collect statistics on the sex composition of business owners or operators. Indeed, statisticians would argue that such statistics are methodologically problematic because many businesses have multiple owners and operators, some of 
whom might be men and some women. However, in the absence of some kind of statistical base, policymakers, bankers and others tend to assume that all businesses are owned and/or operated by men or, to a similar effect that businesses owned or operated by women are no different from those of men. Such differences suggest different needs, and show that in order to make good policy it is essential to make women's businesses visible in terms of numbers, their share of businesses and distinct characteristics.

\section{Gender Inequality: Impediment to Growth and Poverty Reduction}

Women and girls constitute three-fifths of the world's poor. Their poverty level is worse than that of men as clear gender disparities in education, employment opportunities and decision-making power exist. A large number of women are mainly engaged in subsistence agriculture as well as in micro and small-scale enterprises (MSE). In most of the developing countries, women constitute $70-80$ per cent of the total agricultural labour force and they account for over 80 per cent of food production. It is not surprising therefore to find many women engaged in food processing, weaving, personal services, beverage preparation, and selling of snack foods. In the MSE sector worldwide, women make up one-quarter to one-third of the total business population and in manufacturing they constitute one-third of the global labour force. In addition to their economic and income-generating activities, women assume multi-faceted roles in society, i.e. as breadwinner of family, unpaid family workers, service providers in the communities and mother/care-taker of the family.

To respond to the needs of women it requires devising measures to integrate women as decision-makers, participants and beneficiaries in all relevant development activities and to address the totality of problems women face as entrepreneurs, due to the wide spectrum of elements affecting the equitable participation of women in development.

Conceptual Frame Work of The Study

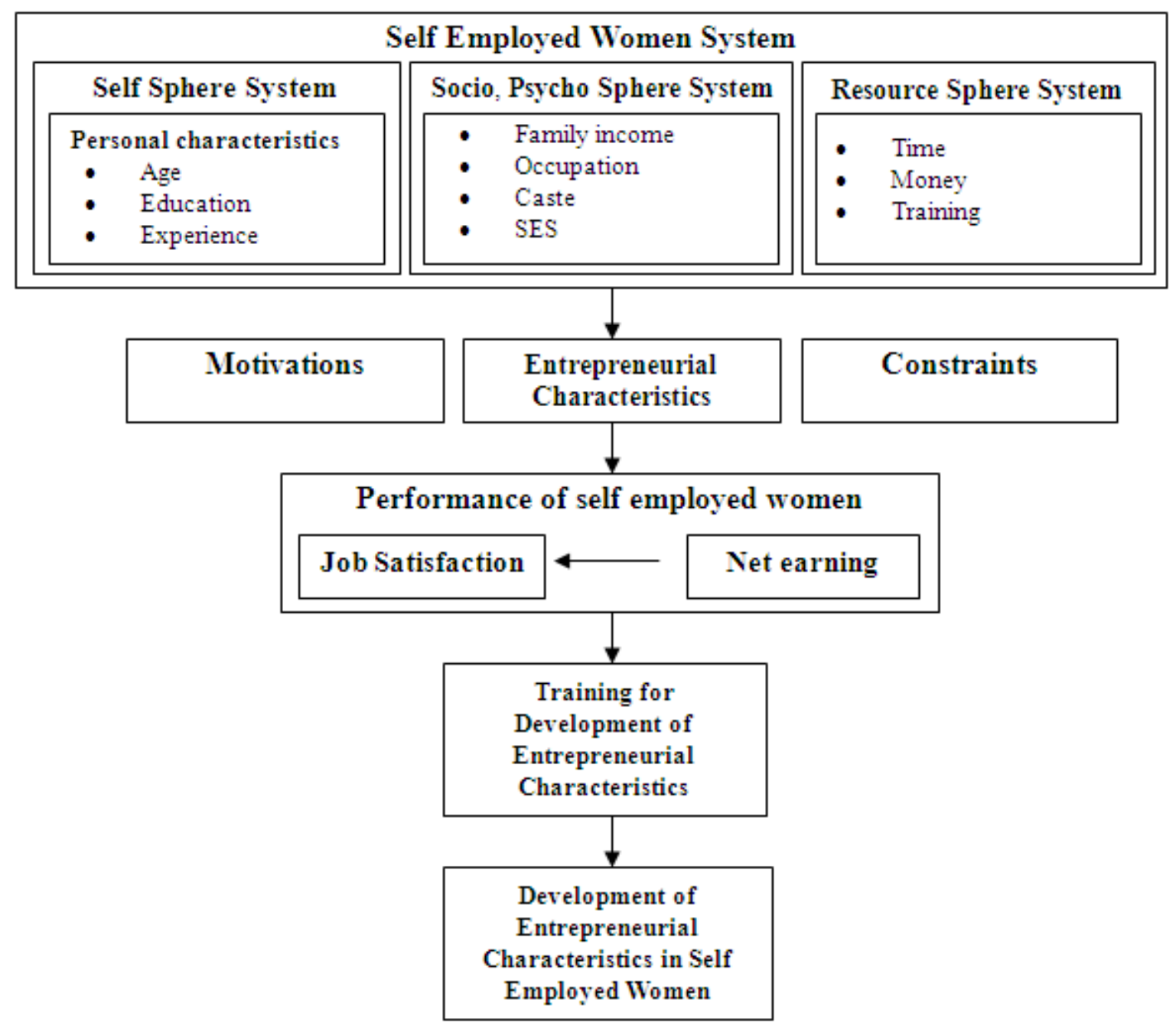




\section{Conceptual Frame Work of the Study}

In the present study, it is conceptualised that performance of self employed women is a function of self-sphere system. Socio psycho system and resource system variable also affects the entrepreneurial characteristics of the respondents. Job satisfaction and net earnings are the determinants of entrepreneurial characteristics. if support- system in the form of training is provided then entrepreneurial characteristics can be developed.

\section{How to Develop Women Entrepreneurs?}

Right efforts on from all areas are required in the development of women entrepreneurs and their greater participation in the entrepreneurial activities. Following efforts can be taken into account for effective development of women entrepreneurs.

- Consider women as specific target group for all developmental programmers.

- Better educational facilities and schemes should be extended to women folk from government part.

- $\quad$ Adequate training programmed on management skills to be provided to women community.

- Encourage women's participation in decision-making.

- Vocational training to be extended to women community that enables them to understand the production process and production management.

- $\quad$ Skill development to be done in women's polytechnics and industrial training institutes. Skills are put to work in training-cum-production workshops.

- $\quad$ Training on professional competence and leadership skill to be extended to women entrepreneurs.

- $\quad$ Training and counselling on a large scale of existing women entrepreneurs to remove psychological causes like lack of self-confidence and fear of success.

- Counselling through the aid of committed NGOs, psychologists, managerial experts and technical personnel should be provided to existing and emerging women entrepreneurs.

- Continuous monitoring and improvement of training programmers.

- Activities in which women are trained should focus on their marketability and profitability.

- Making provision of marketing and sales assistance from government part.

- To encourage more passive women entrepreneurs the Women training programmed should be organized that taught to recognize her own psychological needs and express them

\section{Support Needs of Women Entrepreneurs}

A) Financial support: it includes the following:

- Low cost start up loans.

- Loan funds specifically aimed at women entrepreneurs.

- Grants for business start up.

- Investment grants.
- Tax concessions for women entrepreneurs.

- Equity fund specifically aimed at young entrepreneur.

- Access to loan guarantees.

\section{B) Business support and training Networking}

C) Other issues

- $\quad$ Flexible delivery of business support, to include child care.

- Applied and/or participatory research with women entrepreneurs.

- Support for the establishment of co-operatives.

- Influence by women entrepreneurs over policy before it is decided.

- Support for international networks of women entrepreneurs.

\section{Measures ho Remove hhe Obstacles}

- Need to use experienced entrepreneurs for the provision of advisory services.

- Training in new technology, foreign languages and in business skills.

- The provision of effective financial support.

- The need to ensure informality in the provision of services and the development of networks.

- Emphasised the need for women entrepreneurs to meet internationally.

- Effective networking within the organisation itself is important.

A major change in traditional attitudes and mindsets of people in society is limited to only creation of opportunities for women. Hence, it is imperative to design programmes that will address to attitudinal changes, training, supportive services. The basic requirement in development of women entrepreneurship is to make aware the women regarding her existence, her unique identity and her contribution towards the economic growth and development of country.

\section{Collective Self-help Capacities and Advocacy Roles}

Supporting the initiatives of groups, private sector associations and communities to develop their self-help programmes is important in view of scarce service institutions in rural areas and weak advocacy capacity of rural and women entrepreneurs. Self-help groups empower micro- and small entrepreneurs to identify their needs, plan and implement their own projects, share the benefits of their collective efforts and evaluate their programmes and projects. Rural and women entrepreneurs can establish common projects such as:

- $\quad$ Collective marketing

- Bulk purchasing

- Common facilities, e.g. to share machinery, a warehouse /vehicle/office facilities

- Group-owned enterprises

- Group lending

- $\quad$ Training programmes 


\section{Advantages of Entrepreneurship among Women}

Empowering women is a challenge. Micro enterprises can help to meet these challenges. Micro - enterprises not only enhance national productivity, generate employment but also help to develop economic independence, personal and social capabilities among women. Following are some of the personal and social capabilities, which were developed as result of taking up enterprise among Women:

- Economic empowerment

- Improved standard of living

- Self confidence

- Enhance awareness

- Sense of achievement

- Increased social interaction

- Engaged in political activities

- Increased participation level in gram sabha meeting

- Improvement in leadership qualities

- Involvement in solving problems related to women and community

- Decision making capacity in family and community

Economic empowerment of women by micro entrepreneurship led to the empowerment of women in many things such as socio-economic opportunity, property rights, political representation, social equality, personal right, family development, market development, community development and at last the nation development..

\section{Steps Taken by the Indian Government}

Entrepreneurial growth in developing countries is often constrained by :

- Insufficient funds to set up ventures, and

- Lack of entrepreneurship to perceive opportunities, organize resources and establish and successfully operate the enterprise

Even when financial resources are made available, indigenous women entrepreneurs are not emerging because potential entrepreneurship dormant within them is not nurtured and cultivated.

In order to accelerate formation of indigenous enterprise by women, imaginative development programmes and policies with sound institutional support are needed. This has been very well achieved in India in the last decade. The constraint of finance, which virtually prohibited the entry of women entrepreneurs into business, has been removed by specialized schemes for providing finance from commercial bands and state financial corporations. Encouraged by these schemes, large number of women entrepreneurs from diverse socio-economic backgrounds are coming forward and venturing into business. There has been a further impetus to development of women entrepreneurs in India due to the government policy of giving support in a big way for women Entrepreneurship Development (WED) training programmes.

WED training programmes (content wise) are no different from general ED training for men. The whole WED package consists of :

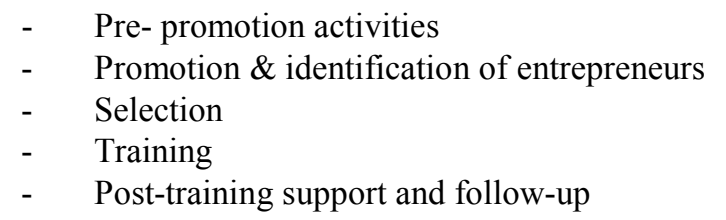

However, special emphasis has to be laid on development of PECs (Personal Entrepreneurial Characteristics ) through training as a part of WED.

The First Five-Year Plan (1951-56) envisaged a number of welfare measures for women. Establishment of the Central Social Welfare Board, organization of Mahila Mandals and the Community Development Programmes were a few steps in this direction.

In the second Five-Year Plan (1956-61), the empowerment of women was closely linked with the overall approach of intensive agricultural development programmes.

The Third and Fourth Five-Year Plans (1961-66 and 1969-74) supported female education as a major welfare measure.

The Fifth Five-Year Plan (1974-79) emphasized training of women, who were in need of income and protection. This plan coincided with International Women's Decade and the submission of Report of the Committee on the Status of Women in India. In1976, Women's welfare and Development Bureau was set up under the Ministry of Social Welfare.

The Sixth Five-Year Plan (1980-85) saw a definite shift from welfare to development. It recognized women's lack of access to resources as a critical factor impending their growth.

The Seventh Five-Year Plan (1985-90) emphasized the need for gender equality and empowerment. For the first time, emphasis was placed upon qualitative aspects such as inculcation of confidence, generation of awareness with regards to rights and training in skills for better employment.

The Eight Five-Year Plan (1992-97) focused on empowering women, especially at the Gross Roots Level, through Panchayati Raj Institutions.

The Ninth Five-Year Plan (1997-2002) adopted a strategy of Women's Component Plan, under which not less than 30 percent of funds/ benefits were earmarked for women related sectors.

The Tenth Five-Year Plan (2002-07) aims at empowering women through translating the recently adopted National Policy for Empowerment of Women (2001) into action and ensuring Survival, Protection and Development of women and children through rights based approach.

The Eleventh Five-Year Plan (2007-12) : emphasized on strengthening women related legislations, institutional mechanisms and empowering women. Envisaged Swayamsiddha and Indira Gandhi Matritva Sahayog Yojana (IGMSY) as the main interventions through Self Help Groups never really took off.

The Twelth Five Year Plan (2012-2017): Emphasizing at raising the sex ratio for age group 0-6 to 935 by 2011-12 and to 950 by $2016-17$ and ensure that at least 33 percent of the 
direct and indirect beneficiaries of all government schemes are women and girl children and free education to them without any compulsion to work.

\section{Women Entrepreneurs in India}

Indra Nooyi: Indian born American businesswoman, Indra Krishnamurthy Nooyi born October 28, 1955 is the Chairperson and Chief Executive Officer (CEO) of PepsiCo.

Dr. Kiran Mazumdar-Shaw: Entrepreneur Dr. Kiran Mazumdar Shaw, Chairman \& Managing Director of Bioon Ltd. She founded Biocon India with a capital of Rs.10,000. in her garage in 1978. Shaw held close to $40 \%$ of the stock of the company and was regarded as India's richest woman with an estimated worth of Rs. 2,100 crore.

Anu Aga: This woman became the Chairperson of Thermax Engineering/ Bombay Management Association awarded her Management Woman Achiever of the Year Award 2002 - 2003. After retiring from Thermax, she took to social work, and 2010 was awarded the Padma Shri (Social Work) by Govt. of India.

Sulajja Firodia Motwani: She is Joint Managing Director of Kinetic Engineering Ltd, she is the in charge of the Company's overall business developmental activities.

Ekta Kapoor: Ekta Kapoor, creative head of Balajji Telefilms, is the daughter of actor Jeetendra, and sister of actor Tushar Kapoor. She is a smart woman with a definite agenda' and has also been appropriately termed as Asia's most powerful communicator and the lady no.1 in Hindi serials and movies.

Simone Tata: With her visions, she changed a small unknown cosmetics company, one of the subsidiaries of Tata Oil Mills, into one of the leading cosmetic companies of India. Lakme changed the face of Indian fashion and cosmetics forever.

Vidya Manohar Chhabria: The wife of late Manohar Rajaram Chhabria, is now a chairman of leading Jumbo Group, a Dubai based $\$ 1.5$ billion business conglomerate. A great lover of Indian cuisine and music, at present, her dream is to develop Jumbo as a focused global entity.

Priya Paul: Priya Paul (born 1967), is a prominent woman entrepreneur of India, and currently the Chairperson of Appeejay The Park Hotels chain of boutique hotels. received several awards like, The Federation of Hotels and Restaurants Association of India conferred on her Young Entrepreneur of the Year award (1999-2000), nominated for The Economic Times Awards as the Businessperson of the year (2002-2003).

\section{Conclusions}

When women moves forward, the family moves, the village moves and the nation moves. These words of Pandit Jawahar Lal Nehru are an accepted fact. Employment gives economic status to women and economic status gives way to social status and there by empowerment to women.

Entrepreneurship among women, no doubt improves the wealth of the nation in general and of the family in particular. Women today are more willing to take up activities that were once considered the preserve of men, and have proved that they are second to no one with respect to contribution to the growth of the economy. Nowadays, they are facing widespread problems from setting of enterprise to the marketing of products. Women entrepreneurship must be moulded properly with entrepreneurial traits and skills to meet the changes in trends, challenges global markets and also be competent enough to sustain and strive for excellence in the entrepreneurial arena.

To respond to the needs of women it requires devising measures to integrate women as decision-makers, participants and beneficiaries in all relevant development activities and to address the totality of problems women face as entrepreneurs, due to the wide spectrum of elements affecting the equitable participation of women in development. A plan or strategy must be designed and implemented in close collaboration with various development partners in different specialized areas, notably: education, health, human rights as well as environment and energy. This would definitely enhance their socio-economic status, a pre-requisite of women's empowerment

We always viewed that a smart woman can pick up a job any day, but if she becomes an entrepreneur she can provide a livelihood to 10 more women at least..!!

\section{REFERENCES}

[1] Bowen, Donald D. \& Hirsch Robert D. (1986). The Female Entrepreneur: A career Development Perspective. Academy of Management Review, Vol. 11No. 2, 393-407.

[2] Carter S. (2000).Gender and Enterprise' in Carter S. and Jones Evans D. (eds).

[3] Carter S. and Cannon T. (1992). Women as Entrepreneurs. London: Academic Press.

[4] Carter S. and Rosa P. (1998). The financing of male- and female-owned businesses. Entrepreneurship \& Regional Development, Vol 10, 225-241

[5] Deshpande, Sunil and Sethi, Sunita. (2009). Women Entrepreneurship In India (Problems, Solutions \& Future Prospects of Development). Shodh, Samiksha aur Mulyankan, Journal of International Research, Vol. II, (9) 10.

[6] Dhameja S K (2002). Women Entrepreneurs: Opportunities, Performance and Problems, Deep Publisher (P) Ltd., New Delhi.

[7] Donald F. Kuratko, Richard M. Hodgetts. (1997). Entrepreneurship. Dryden Press Series in Entrepreneurship, Hardcover, USA Case Study, Dindigul, Tamilnadu, India.

[8] Entrepreneurship and Regional Development, University of Educational Planning and Administration. NUEPA Consortium for Research on Educational Access, Transitions and Equity. Vol. 10 No. 3, 225-241. 
[9] Gordon E. \& Natarajan K. (2007). Entrepreneurship Development. Himalaya Publication House, Second Revised edition.

[10] Goyal, Meenu and Parkash, Jai. (2011). Women Entrepreneurship in India-Problems and Prospects. International Journal of Multidisciplinary Research Vol.1 No.5, 132-137.

[11] Hackler, Darrene; Harpel, Ellen and Mayer, Heike. (2008). Human Capital and Women's Business Ownership. Arlington, Office of Advocacy U.S. Small Business Administration, Vol. $74,323$.

[12] Jalbert, Susanne E. (2008) Women Entrepreneurs in the Global Economy, education research. http://research.brown.edu/pdf/1100924770.pdf.

[13] Lalitha, I. (1991). Women entrepreneurs challenges and strategies, Frederich, Ebert Stiftung, New Delhi.

[14] Madhumita and Ramya Subrahmanican, (2008). Gender equity in deducation : A review of trends \& factors. CREATE research monograph no. 18, Delhi \& Brighton : NUEPA and university \& Sussex

[15] Malaysianurturing (2008). Women Entrepreneurs. United Nations Development Programme (UNDP), Malaysia.

[16] Moore, D. P. \& Buttner, E. H. (1997). Women entrepreneurs: Moving beyond New Generation of Women Entrepreneurs
Achieving Business Success.

[17] Prabha Singh (2009) Rural Women and Development of Entrepreneurship with special reference to Punjab in Empowerment of Rural Women in India Kanishka Publishers, New Delhi. Rural Institute, Dindigul District,

[18] Sathiabama, K. Rural Women Empowerment and Entrepreneurship Development. Research Scholar, Department of Political Science and Development Administration, Gandhigram

[19] Singh, K. (1992). Women entrepreneurs, Ashish publishing house, New Delhi.

[20] Singh, Surinder Pal. (2008). An Insight Into The Emergence Of Women-owned Businesses As An Economic Force In India, presented at Special Conference of the Strategic Management Society, December 12-14, 2008, Indian School of Business, Hyderabad.

[21] Sorokhaibam, Robita and Laishram, Nandita (2011). Women Entrepreneurship In Manipur, North-East India. Interdisciplinary Journal of Research in Business Vol. 1 No. 5 46-53.

[22] Sushma K. C. (2007). An Analysis of Entrepreneurship Development In Women Through Edp Trainings. Thesis Master of Science, Department of Agricultural Extension Education Dharwad Agriculture University, Karnataka.. 